\title{
Erratum to: Polymorphism of the prion protein gene (PRNP) in Polish cattle affected by classical bovine spongiform encephalopathy
}

\author{
Artur Gurgul · Urszula Czarnik • Magdalena Larska • \\ Mirosław P. Polak · Janusz Strychalski • \\ Ewa Słota
}

Published online: 21 February 2012

(C) Springer Science+Business Media B.V. 2012

\section{Erratum to: Mol Biol Rep}

DOI 10.1007/s11033-011-1318-9

In the original publication of the article, inappropriate author name and surname order was given for the second author, Czarnik Urszula. This note corrects this error.

The online version of the original article can be found under doi:10.1007/s11033-011-1318-9.

\footnotetext{
A. Gurgul ( $\square)$

Laboratory of Genomics, National Research Institute of Animal

Production, Krakowska 1, 32-083 Balice n. Krakow, Poland

e-mail: agurgul@izoo.krakow.pl

U. Czarnik · J. Strychalski

Department of Animal Genetics, University of Warmia

and Mazury in Olsztyn, Oczapowskiego 5, 10-824 Olsztyn,

Poland

M. Larska · M. P. Polak

Department of Virology, National Veterinary Research Institute,

Al. Partyzantów 57, 24-100 Puławy, Poland

E. Słota

Department of Animal Immuno- and Cytogenetics, National

Research Institute of Animal Production, Krakowska 1,

32-083 Balice n. Krakow, Poland
} 